University of Michigan Law School

University of Michigan Law School Scholarship Repository

Law \& Economics Working Papers

$10-24-2011$

\title{
The Effective Tax Rate of the Largest US and EU Multinationals
}

Reuven S. Avi-Yonah

University of Michigan Law School, aviyonah@umich.edu

Yaron Lahav

Ben-Gurion University of the Negev, ylahav@som.bgu.ac.il

Follow this and additional works at: https://repository.law.umich.edu/law_econ_current

Part of the Taxation-Transnational Commons, and the Tax Law Commons

\section{Working Paper Citation}

Avi-Yonah, Reuven S. and Lahav, Yaron, "The Effective Tax Rate of the Largest US and EU Multinationals" (2011). Law \& Economics Working Papers. 41.

https://repository.law.umich.edu/law_econ_current/art41

This Article is brought to you for free and open access by University of Michigan Law School Scholarship Repository. It has been accepted for inclusion in Law \& Economics Working Papers by an authorized administrator of University of Michigan Law School Scholarship Repository. For more information, please contact mlaw.repository@umich.edu. 


\title{
THE EFFECTIVE TAX RATES OF THE LARGEST US AND
}

\author{
EU MULTINATIONALS
}

\author{
Reuven Avi-Yonah ${ }^{1}$ and Yaron Lahav ${ }^{2}$
}

\section{Introduction}

The United States has the second highest statutory corporate tax rate in the OECD (after Japan). This has not always been the case: After the 1986 tax reform act lowered the US rate from $46 \%$ to $34 \%$, the US had one of the lowest statutory corporate tax rates in the OECD. However, in the past 25 years, the US rate has remained essentially unchanged (it was raised to $35 \%$ in 1993), while most other OECD countries reduced their statutory rate so that the OECD average statutory corporate tax rate is $25.5 \%{ }^{3}$

Not surprisingly, this situation has led to numerous calls for lowering the US statutory corporate tax rate, on the grounds that it is making US-based multinationals uncompetitive vis-a-vis their counterparts in other OECD countries. Recently, even the Obama Administration, following the lead of some Democrats in Congress, has supported lowering the corporate tax rate. ${ }^{4}$ The current debate is less about whether the corporate rate should be lowered and more about whether such a reform should be revenue neutral, i.e., paid for by eliminating corporate tax expenditures such as deferral, accelerated depreciation, and the tax credit for domestic production.

At the same time, however, there have been a plethora of conflicting claims about the effective tax rate borne by US-based multinationals. Some have stated that like the statutory rate, it is among the highest in the OECD, while others have claimed that it is among the lowest. ${ }^{5}$ This debate is important because it is the effective corporate tax rate

\footnotetext{
${ }^{1}$ Irwin I. Cohn Professor of Law, the University of Michigan.

${ }^{2}$ Assistant Professor of Finance, Ben Gurion University.

${ }^{3}$ This is the unweighted average of the OECD excluding the US. The weighted OECD average excluding the US, which takes into account the relative size of various economies, is $29.6 \%$.

${ }^{4}$ Obama Backs Corporate Rate Cut Along With Tax Simplification, Bloomberg, Jan. 26, 2011.

${ }^{5}$ See, e.g., Amy S. Elliott, Large U.S. Firms' Effective Tax Rates Surpass OECD Average, Survey Says, 2011 TNT 733 (April 15, 2011); Kevin A. Hassett and Aparna Mathur, Report Card on Effective Corporate Tax Rates: United States Gets an F, 1 TAX Policy Outlook, American Enterprise InStitute for Public Policy ReSearch (February, 2011); but cf. David Kocieniewski, U.S. Business Has High Tax Rates but Pays Less, New York TIMES (May 2, 2011); Chuck Marr and Brian Highsmith, Six Test for Corporate Tax Reform, CENTER on BudGet AND Policy PRIORITIES (February 28, 2011); U.S. is One of the Least Taxed Developed Countries, Citizens for TAX JUSTICE (June 30, 2011); Analysis: 12 Corporations Pay Effective Tax Rate of Negative 1.5\% on \$171 Billion in Profits: Reap \$62.4 Billion in Tax Subsidies, CITIZENS FOR TAX JUSTICE (June 1, 2011).
} 
and not the statutory rate that most directly affects the competitiveness of US-based multinationals against multinationals based in other OECD jurisdictions.

However, neither side has data to support its claims. Almost all existing studies of the effective tax rate on US-based multinationals focus only on those companies, and do not attempt to compare them with multinationals based in other countries. ${ }^{6}$ The only exception is a recent study commissioned by the Business Roundtable and executed by PricewaterhouseCoopers. ${ }^{7}$ However, as discussed below, this study suffers from numerous flaws, the most important of which is that it includes 2000 companies from 58 foreign countries and therefore has many companies that are not serious competitors of large USbased multinationals (e.g., companies based in Morocco, Kazakhstan, Nigeria, Jordan, Lebanon and Oman).

The competitiveness issue is primarily about the ability of the largest US multinationals to compete with their counterparts based in other countries, and especially those based in the EU (since Japanese multinationals are known to be subject to higher statutory and effective tax rates than US ones, and therefore they are less relevant to this debate). ${ }^{8} \mathrm{We}$ have therefore decided to study the overall effective tax rates of the largest 100 US-based multinationals over the past decade, and compare them with the effective tax rates of the largest 100 EU-based multinationals. ${ }^{9}$ In our opinion, this is the comparison that is most relevant to resolving the competitiveness issue, because (a) it focuses only on large multinationals in the most relevant jurisdictions ${ }^{10}$, (b) it focuses on the overall effective tax rate borne by each group of multinationals, and not on other issues such as the statutory tax rate, the effective tax rate on foreign source income, or whether dividends from active income can be repatriated tax free. Those issues, while important for other

\footnotetext{
${ }^{6}$ See, e.g., Scott D. Dryeng and Bradley P. Lindsey, Using Financial Accounting Data to Examine the Effect of Foreign Operations Located in Tax Havens and Other Countries on US Multinational Firms' Tax Rates (2009); Harry Grubert, Foreign Taxes, Domestic Income, and the Jump in the Share of Multinational Income Abroad: Sales Aren't Being Globalized, Only Profits (2009); Rosanne Altshuler and Harry Grubert, The Three Parties in the Race to the Bottom: Host Governments, Home Governments and Multinational Companies, 7 Fla. Tax Rev. 153 (2005); George K. Yin, How Much Tax Do Large Public Corporations Pay? Estimating the Effective Tax Rates of the S\&P 500, 89 Va. L. Rev 1793 (2003). The Swenson and Lee and Markle and Shackleford studies discussed below focus on ETRs of countries, although they base that on studying the financial data of MNEs from those countries.

${ }^{7}$ http://businessroundtable.org/uploads/studies-reports/downloads/Effective Tax Rate Study.pdf.

${ }^{8}$ Charles Swenson and Namryoung Lee, The Jury is In: US Companies are Overtaxed Relative to Their International Competitors, at www.cpa2biz.com/Content/media/Producer Content.Newsletters/Articles 2008/Tax/Jurinin.jsp. (Japanese median ETR for 2006-7 was 41\%); Kevin S. Markle and Douglas Shackleford, Cross-Country Comparisons of Corporate Income Tax Rates, NBER Working Paper 16839 (Feb. 2011) (in a study of 11,602 public corporations from 82 countries for 1988-2009, Japanese firms always faced the highest ETRs).

${ }^{9}$ We also calculated AETRs for the 150 largest multinationals listed in the most recent UN World Investment Report, for US, EU and Asian multinationals. Over the last 10 years (2001-2010), effective tax rate for American, EU and Asian companies was 33, 37 and 38 percent respectively. For FYE2010, the rates for American, EU and Asian companies are 31, 31 and 35 percent respectively. For FYE2009, the rates for American, EU and Asian companies are 26, 33 and 39 percent respectively. Thus, in no case was the AETR for the US companies higher than that of the EU or Asian based companies. Note, however, that this list only includes the 23 largest US-based multinationals (as ranked by the UN).

${ }^{10}$ For the US, the Forbes 2000 list for 2011 includes 536 companies. The top 100 (19\%) account for $57 \%$ of the revenues and $77 \%$ of the profits of those companies, suggesting that to study competitiveness we should focus on these companies.
} 
purposes (e.g., transfer pricing or the "lock out" effect), are in our view irrelevant to the competitiveness issue.

\section{Methodology}

To find the 100 biggest U.S. companies and the 100 biggest European companies, we used the list of Forbes 2000 biggest public companies for 2011, as published in Forbes magazine's website ${ }^{11}$. We then constructed our database by choosing the most highly ranked U.S. and European companies respectively. The list of the 200 chosen companies is presented in Table 1.

We then searched the COMPUSTAT database (both North America and Global) to find financial data of the chosen companies. For every company in our list of chosen companies, we found the pretax income, net income and current income tax for the fiscal years $2001-2010$.

If, for some reason, a certain company did not have any financial data available on the COMPUSTAT database for all fiscal years mentioned, we did not include it in our database and replaced it by the next highest ranked company on the Forbes 2000 list. We then translated all financial data into U.S. dollars using annual exchange rates taken from OANDA website ${ }^{12}$. At the end of this process, we obtained a database of 200 companies (100 U.S. companies and 100 European companies) with at least one year of financial data between 2001 and 2010. Table 2 describes the distribution of companies by country of residence.

Comparing the effective tax rates in each region (Europe and the U.S.), we calculated aggregate effective tax rate as follows:

$$
\operatorname{AETR}_{i, t}=\frac{\sum_{j} T_{j, t}}{\sum_{j} P I_{j, t}}
$$

where $A E T R_{i, t}$ is the aggregate effective tax rate of region $i$ during period $t$. The numerator is the sum of all current income taxes paid by the companies residing in region $i$ (indexed $j$ ) during period $t$ and the denominator is the sum of all pretax income paid by the companies residing in region $i$ during the same period. Naturally, the COMPUSTAT database may not have the relevant data to calculate this measure for all companies during all fiscal years. For this reason, we only used available data that can be found either directly (i.e. both pretax income and current income tax are available) or indirectly (i.e. either pretax income or current income tax can be found by adding current and deferred income tax to net income or subtracting deferred income tax and net income from pretax income respectively).

\footnotetext{
${ }^{11}$ See www.forbes.com/global2000.

${ }^{12}$ See $\underline{\text { www.oanda.com/currency/converter. }}$
} 
The AETR is therefore a measure of effective tax rate paid by the business sector in every region. Our decision to use aggregate measures in our study is a result of (what we see as) a bias that can occur when using some kind of average (either weighted or not) of effective tax rates of individual companies. This bias is more significant when companies have a relatively low (or even negative) pretax income. When this is the case, all deviation from the current (say, 35\% in the case of U.S. companies) tax provision may strongly affect the effective tax rate. To illustrate this, consider the following example with two companies, A and B. Both companies' revenues in a given year equal $\$ 1,000,000$. The pretax profits, however, are different and equal $\$ 100,000$ and $\$ 10,000$ respectively. If both pay $35 \%$ of pretax income as income tax, then the AETR is $35 \%$. Assume now that there is a tax credit to company $\mathrm{A}$ on the amount of $\$ 2,000$. This adjustment will decrease the effective tax rate of company A by approximately 6\% (from 35\% to 33\%). However, if the same adjustment was made to company $\mathrm{B}$, the effective tax rate would decrease by approximately $57 \%$ (from $35 \%$ to 15\%). This difference would also affect the average effective tax rate if weighted by revenues. If the tax adjustment was made to company A, the new average effective tax rate would be $34 \%$. If, on the other hand, the adjustment was made to company B, the new average effective tax rate would be $25 \%$. A similar example can show biased calculations when the average effective tax rate is weighted by any variables other than pretax profit.

Several ways are used in the literature to avoid this bias. One way (used in the PwC study mentioned above) is to eliminate outliers. It is reasonable to assume that relatively low (or negative) pretax income generates either too high or too low (or negative) effective tax rates. For this reason, in cases where either too high or too low effective tax rate is detected, the observation is eliminated. However, it is our view that outliers in this context are part of the data. Furthermore, when the aggregate effective tax rate is calculated the way we do, relatively low pretax income and relatively low income tax will have relatively low effect on the measure. A tax credit to a company with low or negative pretax income is not an outlier. It should therefore be treated the way it is: part of the total income tax collected by the tax authority during the tested period.

In other cases, it is possible that such elimination will result with keeping the outliers. To illustrate this, consider the above example and assume that the researcher chooses to exclude companies with non-positive effective tax rates. Assume now that company A received a tax credit of $\$ 20,000$ and company received a tax credit of $\$ 3,500$. The researcher will exclude company $B$ because of a relatively small tax adjustment, where company B will still be part of the data with a much larger tax adjustment. To sum, excluding outliers does not ensure the isolation of companies with reasonable effective tax rate on one hand, and does not provide accurate results on the other hand.

Another way is to aggregate data across periods. If a certain company showed an abnormal tax rate in a certain year, then aggregating income taxes over several years should dismiss small or insignificant deviations from standard tax rate levels. For this reason, in addition to annual analysis, we also provide results across ten years of study. 


\section{Results}

AETR values of each region are presented in Table 3 for different fiscal years and for the last decade. The table shows that in eight out of ten years, the European AETR is higher than the U.S. AETR. In addition, the European AETR is also higher for the period 2001 2010.

As can be seen in table 3, results for the fiscal year 2008 show abnormally high AETRs. We believe that it is somehow connected to the economic downturn that stroke at the beginning of that year. For this reason, and in order to maintain the comparability of the results, we excluded this year from the calculated AETR for the decade and present in the second row from the bottom the AETR for the fiscal years 2001 - 2007, 2009 and 2010. Lastly, in case abnormality persisted to later year, we present in the bottom row aggregated results for the fiscal years 2001 - 2007 only. Overall, these adjustments resulted in minor modifications to the initial results presented for the decade (third row from the bottom). We can therefore conclude that according to the analysis, US companies pay, on average, effective tax rate of approximately 30\%, and European companies pay, on average, effective tax rate of approximately $34 \%$.

Figure 1 describes the distribution of companies from each region by industry. The figure shows that the distribution is relatively similar across regions. We can also learn from the figure that in both regions, about half the companies are defined as manufacturers. Table 4 shows the AETRs of each region for the years 2001 - 2011 for each industry segment separately. According to the table, The US AETRs are lower in the manufacturing, transportation, services and public administration segment, while the European AETRs are lower in the mining, trade and finance segments.

\section{Discussion}

Our results are the opposite from those found in the PwC study, even though the PwC study used the same methodology (i.e. calculated AETR as aggregate income tax divided by aggregate pretax income). However, in our opinion the PwC study is flawed, and should not be taken as an indication that US based multinationals are subject to a higher AETR than their counterparts from other countries. The reasons for this conclusion are as follows:

1. PwC used all 2000 companies in the Forbes Global database, while we used only the largest 200 (100 U.S. and 100 EU). As explained above, in our opinion focusing on the largest companies is more closely related to competitiveness.

2. PwC calculated results only for the years 2006-2009, while we calculated between 2001 and 2010. Including a longer time frame improves the reliability of our results.

3. PwC compared U.S. companies to those from 58 other countries, not to European companies as a group (although they did compare U.S. to OECD countries). We used the 
biggest 100 U.S and biggest 100 European companies. In our opinion this method is more relevant to the competitiveness question because the $\mathrm{PwC}$ includes many companies from small countries that do not provide serious competition to large US multinationals (e.g., Morocco).

4. PwC eliminated outliers, while we did not. As explained above, outliers can have an important impact on the results and there is no reason to assume they are irrelevant in this context. By eliminating outliers, PwC limited themselves to conventional cases only (i.e. only to those companies with effective tax rate in the $20 \%-40 \%$ range). In our opinion, this analysis is all about the outliers. We are looking for the special cases that make the difference. This is why we only include the top 100 companies from each group. In such a small number, any tax holiday should make the difference, so it is important to include outliers.

5. For income tax, PwC used current income tax and changes in deferred tax, while we used only current income tax. While over a ten year period one might expect that most deferred taxes will become current taxes, in our opinion using deferred taxes can be misleading because they just represent one accounting firm's best guess as to whether taxes will have to be paid. For example, under FIN 48 deferred taxes have to be booked if a transaction that avoids taxation has a $50 \%$ chance of being upheld by the courts if challenged by the IRS, but not if it has a 51\% chance (in the opinion of the accounting firm). In addition, deferred taxes may or may not include the tax on repatriations, depending on the company's assertion that the earnings are or are not permanently reinvested overseas, which in turn assumes that the tax law relating to repatriations will remain unchanged. In our opinion these determinations are too flimsy a basis to calculate AETRs reliably. Using only current taxes insures that the AETR reflects taxes that have actually been paid or accrued.

6. Table 1 of the PwC study provides a list of 59 countries that were included in the analysis. But from tables A1 to A4 of the appendix to the PwC study, only 13 countries have more than 30 observations in each year. This means that for all the rest, it cannot be assumed (statistically) that the results properly represent the real populations. Among these 13, the U.S. ranked number 7 (right in the middle). In addition, the AETRs of some countries from the 59 are based on one observation, which cannot be representative.

In contrast with the PwC study, our results are consistent with previous studies that have focused on comparing the ETRs of various jurisdictions. ${ }^{13}$ For example, Markle and Shackleford compared the US effective corporate tax rate in 2005-2009 with the ETRs of Canada, France, Germany, Japan and the UK and found that the US ETR was 23\% while the average weighted ETR of the other six countries was $24.5 \% .{ }^{14}$ Swenson and Lee compared ETRs in 2006 and found that the US ETR was 29.5\% while the OECD weighted average ETR was $28.4 \% .{ }^{15}$ For the 15 largest countries, Swenson and Lee concluded that

\footnotetext{
${ }^{13}$ For a summary of the literature see Jane G. Gravelle, International Corporate Tax Rate Comparisons and Policy Implications (CRS, March 31, 2011).

${ }^{14}$ Kevin S. Markle and Douglas A. Shackleford, Cross Country Comparisons of Corporate Income Taxes, working paper (February 2011). This study compared ETRs of 11,602 public corporations from 82 countries from 1988 to 2009, so it is hard to draw conclusions from it in regard to competitiveness because it includes so many companies from small countries that do not pose serious competition to US MNEs.

${ }^{15}$ Charles Swenson and Namryoung Lee, The Jury is In: US Companies are Overtaxed Relative to Their International Competitors, AICPA, July 17, 2008.
} 
the weighted average ETR in 2006 was 28.7\% (compared to the US 29.5\%). ${ }^{16} \mathrm{~A}$ PwC study from 2008 concluded that the US ETR was $27.1 \%$ while the weighted average for the OECD excluding the US was $27.7 \%$; for the fifteen largest countries outside the US, the weighted average ETR was $27.2 \% .{ }^{17}$ As Gravelle concluded, these studies all confirm that "effective tax rates in the United States and in other countries are similar."18

\section{Conclusion}

We believe that this study indicates that US-based multinationals do not face a tax induced competitive disadvantage in competing against EU-based multinationals. Even though the US statutory rate is ten percentage points higher than the average corporate statutory rate in the EU, the effective US corporate tax rate is the same or lower than the effective EU corporate tax rate for the largest US and EU multinationals.

Presumably, the reason for this result is that while the EU countries have a lower statutory rate, their tax base is larger because it has fewer exceptions. In fact, a comparison of the CFC rules of the US (Subpart F) and the major EU jurisdictions (UK, Germany, Italy, France) indicates that the EU CFC rules tend to be tougher than Subpart F because (a) they take into account the effective tax rate in the source country in deciding whether to tax income from a CFC, and (b) they take into account whether the CFC has a real presence in the source country. Under the EU rules, for example, a bank earning interest income in a tax haven is likely to be subject to current tax because the effective tax rate in the haven is low and the bank does not have a real presence in the haven. Under Subpart F the income will likely qualify for the active financing exception. In addition, the EU does not have anything like the US rules that enable US multinationals to shift profits from high tax to low tax CFCs without incurring a US tax cost (check the box and IRC 954(c)(6)).

This conclusion suggests that the US can in fact reduce its corporate tax rate to the EU average in a revenue neutral fashion without affecting the competitiveness of US-based multinationals, since such a move would simply result in a tax regime that is more similar to that faced by EU companies. Specifically, as many observers have recommended, it should be possible to abolish deferral altogether if the US rate were reduced sufficiently. Such a move would have tremendous simplification potential since it would be possible to get rid of both Subpart F and outbound transfer pricing enforcement, and it would eliminate the "lock out" problem as well (since repatriations would not be taxed). Alternatively, it should be possible to amend Subpart F to take the source country rate into account, so that an effective source rate that is below $90 \%$ of the US statutory rate would result in a Subpart F inclusion, while reducing the US statutory rate. Such a move, while not as radically simplifying as abolishing deferral, will significantly reduce the pressure on outbound transfer pricing while not resulting in a competitive disadvantage to US-based multinationals or inducing more profit shifting from the US to low taxed offshore locations, like the current rules do.

\footnotetext{
16 Ibid.

${ }^{17}$ PricewaterhouseCoopers, Global Effective Tax Rate Comparisons- Methodology and Results (2008).

${ }^{18}$ Gravelle, supra, 5. Gravelle also reports comparisons of marginal effective tax rates, but those are more suspect because they rely on a hypothetical firm, rather than actual taxes paid by real firms.
} 
Table 1: The 200 chosen companies. The companies are ordered by their rank, sales, profits, assets and market value are as published by the Forbes $\mathbf{2 0 0 0}$ website.

\begin{tabular}{|c|c|c|c|c|c|c|}
\hline Rank & Company & Country & Sales & Profits & Assets & Market Value \\
\hline 1 & JPMorgan Chase & United States & \$115.5 B & $\$ 17.4 \mathrm{~B}$ & $\$ 2,117.6 \mathrm{~B}$ & $\$ 182.2 \mathrm{~B}$ \\
\hline 2 & HSBC Holdings & United Kingdom & $\$ 103.3 \mathrm{~B}$ & $\$ 13.3 \mathrm{~B}$ & $\$ 2,467.9 \mathrm{~B}$ & $\$ 186.5$ B \\
\hline 3 & General Electric & United States & $\$ 150.2 \mathrm{~B}$ & $\$ 11.6 \mathrm{~B}$ & $\$ 751.2 \mathrm{~B}$ & $\$ 216.2 \mathrm{~B}$ \\
\hline 4 & ExxonMobil & United States & $\$ 341.6$ B & $\$ 30.5 \mathrm{~B}$ & $\$ 302.5 \mathrm{~B}$ & $\$ 407.2 \mathrm{~B}$ \\
\hline 5 & Royal Dutch Shell & Netherlands & $\$ 369.1 \mathrm{~B}$ & $\$ 20.1 \mathrm{~B}$ & $\$ 317.2 \mathrm{~B}$ & $\$ 212.9 \mathrm{~B}$ \\
\hline 8 & Berkshire Hathaway & United States & $\$ 136.2 \mathrm{~B}$ & $\$ 13 \mathrm{~B}$ & $\$ 372.2 \mathrm{~B}$ & $\$ 211 \mathrm{~B}$ \\
\hline 10 & Citigroup & United States & $\$ 111.5 \mathrm{~B}$ & $\$ 10.6 \mathrm{~B}$ & $\$ 1,913.9$ B & $\$ 132.8 \mathrm{~B}$ \\
\hline 11 & Wells Fargo & United States & $\$ 93.2 \mathrm{~B}$ & $\$ 12.4 \mathrm{~B}$ & $\$ 1,258.1 \mathrm{~B}$ & $\$ 170.6 \mathrm{~B}$ \\
\hline 11 & BNP Paribas & France & $\$ 130.4 \mathrm{~B}$ & $\$ 10.5 \mathrm{~B}$ & $\$ 2,680.7 \mathrm{~B}$ & $\$ 88 \mathrm{~B}$ \\
\hline 13 & Banco Santander & Spain & $\$ 109.7$ B & $\$ 12.8 \mathrm{~B}$ & $\$ 1,570.6$ B & $\$ 94.7$ B \\
\hline 14 & AT\&T & United States & $\$ 124.3 \mathrm{~B}$ & $\$ 19.9 \mathrm{~B}$ & $\$ 268.5 \mathrm{~B}$ & $\$ 168.2 \mathrm{~B}$ \\
\hline 16 & Chevron & United States & \$189.6 B & \$19 B & $\$ 184.8 \mathrm{~B}$ & $\$ 200.6$ B \\
\hline 18 & Wal-Mart Stores & United States & $\$ 421.8 \mathrm{~B}$ & $\$ 16.4 \mathrm{~B}$ & $\$ 180.7 \mathrm{~B}$ & $\$ 187.3 \mathrm{~B}$ \\
\hline 19 & Total & France & $\$ 188.1 \mathrm{~B}$ & $\$ 14.2 \mathrm{~B}$ & $\$ 192.8 \mathrm{~B}$ & $\$ 138$ B \\
\hline 20 & Allianz & Germany & $\$ 142.9 \mathrm{~B}$ & $\$ 6.7 \mathrm{~B}$ & $\$ 838.4 \mathrm{~B}$ & $\$ 62.7 \mathrm{~B}$ \\
\hline 22 & ConocoPhillips & United States & $\$ 175.8 \mathrm{~B}$ & $\$ 11.4 \mathrm{~B}$ & $\$ 156.3 \mathrm{~B}$ & $\$ 109.1 \mathrm{~B}$ \\
\hline 24 & Volkswagen Group & Germany & \$168.3 B & $\$ 9.1 \mathrm{~B}$ & $\$ 267.5 \mathrm{~B}$ & $\$ 70.3 \mathrm{~B}$ \\
\hline 26 & Nestlé & Switzerland & $\$ 112 \mathrm{~B}$ & $\$ 36.7 \mathrm{~B}$ & $\$ 117.7 \mathrm{~B}$ & \$181.1 B \\
\hline 27 & Vodafone & United Kingdom & $\$ 67.5 \mathrm{~B}$ & $\$ 13.1 \mathrm{~B}$ & $\$ 236.6 \mathrm{~B}$ & $\$ 148.2 \mathrm{~B}$ \\
\hline 28 & ENI & Italy & $\$ 130.5 \mathrm{~B}$ & $\$ 8.4 \mathrm{~B}$ & $\$ 176.1 \mathrm{~B}$ & $\$ 96.8 \mathrm{~B}$ \\
\hline 29 & American Intl Group & United States & $\$ 77.3 \mathrm{~B}$ & $\$ 7.8 \mathrm{~B}$ & $\$ 683.4 \mathrm{~B}$ & $\$ 67.1 \mathrm{~B}$ \\
\hline 29 & GDF Suez & France & $\$ 113.1 \mathrm{~B}$ & $\$ 6.2 \mathrm{~B}$ & $\$ 245.5 \mathrm{~B}$ & $\$ 85.2 \mathrm{~B}$ \\
\hline 31 & IBM & United States & $\$ 99.9 \mathrm{~B}$ & $\$ 14.8 \mathrm{~B}$ & $\$ 113.4 \mathrm{~B}$ & $\$ 198.1 \mathrm{~B}$ \\
\hline 31 & Telefónica & Spain & $\$ 81.3 \mathrm{~B}$ & $\$ 13.6 \mathrm{~B}$ & $\$ 166.5 \mathrm{~B}$ & $\$ 113.3 \mathrm{~B}$ \\
\hline 35 & Procter \& Gamble & United States & $\$ 79.6 \mathrm{~B}$ & $\$ 11.2 \mathrm{~B}$ & $\$ 134.3 \mathrm{~B}$ & $\$ 172.2 \mathrm{~B}$ \\
\hline 36 & Pfizer & United States & $\$ 67.8 \mathrm{~B}$ & $\$ 8.3 \mathrm{~B}$ & \$195 B & $\$ 155.7 \mathrm{~B}$ \\
\hline 37 & Goldman Sachs Group & United States & $\$ 46 \mathrm{~B}$ & $\$ 8.4 \mathrm{~B}$ & $\$ 911.3 \mathrm{~B}$ & $\$ 90 \mathrm{~B}$ \\
\hline 38 & E.ON & Germany & $\$ 124.6 \mathrm{~B}$ & $\$ 7.9 \mathrm{~B}$ & $\$ 205.1 \mathrm{~B}$ & $\$ 64$ B \\
\hline 39 & ING Group & Netherlands & $\$ 149.2$ B & $\$ 4.3 \mathrm{~B}$ & $\$ 1,665.3$ B & $\$ 46.8 \mathrm{~B}$ \\
\hline 40 & UBS & Switzerland & $\$ 49.8 \mathrm{~B}$ & $\$ 7.7 \mathrm{~B}$ & $\$ 1,403 \mathrm{~B}$ & $\$ 70.8 \mathrm{~B}$ \\
\hline 41 & Barclays & United Kingdom & $\$ 63.9 \mathrm{~B}$ & $\$ 5.6 \mathrm{~B}$ & $\$ 2,328.3 \mathrm{~B}$ & $\$ 58.3 \mathrm{~B}$ \\
\hline 42 & Hewlett-Packard & United States & $\$ 127.2 \mathrm{~B}$ & $\$ 9.1 \mathrm{~B}$ & $\$ 119.9 \mathrm{~B}$ & $\$ 90.3 \mathrm{~B}$ \\
\hline 43 & Daimler & Germany & $\$ 130.9 \mathrm{~B}$ & $\$ 6 \mathrm{~B}$ & $\$ 178.7 \mathrm{~B}$ & $\$ 70.5 \mathrm{~B}$ \\
\hline 44 & Société Générale & France & $\$ 85.4 \mathrm{~B}$ & $\$ 5.3 \mathrm{~B}$ & $\$ 1,518.7 \mathrm{~B}$ & $\$ 46.9 \mathrm{~B}$ \\
\hline 45 & Siemens & Germany & $\$ 103.5 \mathrm{~B}$ & $\$ 5.3 \mathrm{~B}$ & $\$ 135 \mathrm{~B}$ & $\$ 110.2 \mathrm{~B}$ \\
\hline 47 & Apple & United States & $\$ 76.3 \mathrm{~B}$ & $\$ 16.6 \mathrm{~B}$ & $\$ 86.7 \mathrm{~B}$ & $\$ 324.3 \mathrm{~B}$ \\
\hline 48 & AXA Group & France & $\$ 162.4 \mathrm{~B}$ & $\$ 3.7 \mathrm{~B}$ & $\$ 981.8 \mathrm{~B}$ & $\$ 46.4 \mathrm{~B}$ \\
\hline 50 & Microsoft & United States & $\$ 66.7 \mathrm{~B}$ & $\$ 20.6 \mathrm{~B}$ & $\$ 92.3 \mathrm{~B}$ & $\$ 215.8 \mathrm{~B}$ \\
\hline 54 & Ford Motor & United States & $\$ 129 \mathrm{~B}$ & $\$ 6.6 \mathrm{~B}$ & $\$ 164.7 \mathrm{~B}$ & $\$ 54.3 \mathrm{~B}$ \\
\hline 55 & ENEL & Italy & $\$ 96.5 \mathrm{~B}$ & $\$ 5.9 \mathrm{~B}$ & $\$ 217.4 \mathrm{~B}$ & $\$ 54 \mathrm{~B}$ \\
\hline 57 & Johnson \& Johnson & United States & $\$ 61.6 \mathrm{~B}$ & $\$ 13.3 \mathrm{~B}$ & $\$ 102.9 \mathrm{~B}$ & $\$ 163.3 \mathrm{~B}$ \\
\hline 58 & Rio Tinto & United Kingdom & $\$ 56.6 \mathrm{~B}$ & $\$ 14.3 \mathrm{~B}$ & $\$ 112.4 \mathrm{~B}$ & $\$ 131.6 \mathrm{~B}$ \\
\hline 59 & Credit Suisse Group & Switzerland & $\$ 53.9 \mathrm{~B}$ & $\$ 5.2 \mathrm{~B}$ & $\$ 1,097.1 \mathrm{~B}$ & $\$ 50.7 \mathrm{~B}$ \\
\hline 60 & Statoil & Norway & $\$ 90.4 \mathrm{~B}$ & $\$ 6.5 \mathrm{~B}$ & $\$ 110.3 \mathrm{~B}$ & $\$ 83.8 \mathrm{~B}$ \\
\hline
\end{tabular}




\begin{tabular}{|c|c|c|c|c|c|c|}
\hline Rank & Company & Country & Sales & Profits & Assets & Market Value \\
\hline 62 & Deutsche Bank & Germany & $\$ 61.2 \mathrm{~B}$ & $\$ 3.1 \mathrm{~B}$ & $\$ 2,556.5 \mathrm{~B}$ & $\$ 59.6 \mathrm{~B}$ \\
\hline 62 & Novartis & Switzerland & $\$ 50.6 \mathrm{~B}$ & $\$ 9.8 \mathrm{~B}$ & $\$ 123.3 \mathrm{~B}$ & $\$ 125.2 \mathrm{~B}$ \\
\hline 64 & Verizon Communications & United States & $\$ 106.6$ B & $\$ 2.5 \mathrm{~B}$ & $\$ 220 \mathrm{~B}$ & $\$ 101.3 \mathrm{~B}$ \\
\hline 66 & BBVA-Banco Bilbao Vizcaya & Spain & $\$ 43.4 \mathrm{~B}$ & $\$ 6.3 \mathrm{~B}$ & $\$ 734.1 \mathrm{~B}$ & $\$ 52.3 \mathrm{~B}$ \\
\hline 72 & BMW Group & Germany & $\$ 80.2 \mathrm{~B}$ & $\$ 4.3 \mathrm{~B}$ & $\$ 146.1 \mathrm{~B}$ & $\$ 51 \mathrm{~B}$ \\
\hline 73 & BASF & Germany & $\$ 85.5 \mathrm{~B}$ & $\$ 6.1 \mathrm{~B}$ & $\$ 78.2 \mathrm{~B}$ & $\$ 74.2 \mathrm{~B}$ \\
\hline 74 & France Telecom & France & $\$ 60.9 \mathrm{~B}$ & $\$ 6.5 \mathrm{~B}$ & $\$ 120.5 \mathrm{~B}$ & $\$ 56.7 \mathrm{~B}$ \\
\hline 81 & Morgan Stanley & United States & $\$ 38 \mathrm{~B}$ & $\$ 4.7 \mathrm{~B}$ & $\$ 807.7 \mathrm{~B}$ & $\$ 43.8 \mathrm{~B}$ \\
\hline 81 & Sanofi-aventis & France & $\$ 40.7 \mathrm{~B}$ & $\$ 7.3 \mathrm{~B}$ & $\$ 110.3 \mathrm{~B}$ & $\$ 89.2 \mathrm{~B}$ \\
\hline 83 & MetLife & United States & $\$ 52.7 \mathrm{~B}$ & $\$ 2.8 \mathrm{~B}$ & $\$ 730.9 \mathrm{~B}$ & $\$ 48.4 \mathrm{~B}$ \\
\hline 86 & PepsiCo & United States & $\$ 57.8 \mathrm{~B}$ & $\$ 6.3 \mathrm{~B}$ & $\$ 68.2 \mathrm{~B}$ & $\$ 102.6$ B \\
\hline 87 & Cisco Systems & United States & $\$ 42.4 \mathrm{~B}$ & $\$ 7.6 \mathrm{~B}$ & $\$ 82 \mathrm{~B}$ & $\$ 99.2 \mathrm{~B}$ \\
\hline 89 & Roche Holding & Switzerland & $\$ 50.8 \mathrm{~B}$ & $\$ 9.3 \mathrm{~B}$ & $\$ 62.9 \mathrm{~B}$ & $\$ 120.9 \mathrm{~B}$ \\
\hline 90 & ArcelorMittal & Luxembourg & $\$ 78 \mathrm{~B}$ & $\$ 2.9 \mathrm{~B}$ & \$130.9 B & $\$ 53.6 \mathrm{~B}$ \\
\hline 91 & Coca-Cola & United States & $\$ 35.1 \mathrm{~B}$ & \$11.8 B & $\$ 72.9 \mathrm{~B}$ & \$148.7 B \\
\hline 92 & Deutsche Telekom & Germany & $\$ 83.6$ B & $\$ 2.3 \mathrm{~B}$ & $\$ 164.6$ B & $\$ 60.7 \mathrm{~B}$ \\
\hline 93 & Intel & United States & $\$ 43.6$ B & $\$ 11.5$ B & $\$ 63.2 \mathrm{~B}$ & $\$ 114.5$ B \\
\hline 96 & Anheuser-Busch & Belgium & $\$ 36.8 \mathrm{~B}$ & $\$ 4.1 \mathrm{~B}$ & $\$ 113.8 \mathrm{~B}$ & $\$ 90.6 \mathrm{~B}$ \\
\hline 100 & EDF Group & France & $\$ 87.2 \mathrm{~B}$ & $\$ 1.4 \mathrm{~B}$ & $\$ 319.9 \mathrm{~B}$ & $\$ 78.2 \mathrm{~B}$ \\
\hline 101 & Repsol YPF & Spain & $\$ 62.2 \mathrm{~B}$ & $\$ 6.2 \mathrm{~B}$ & $\$ 90.4 \mathrm{~B}$ & $\$ 39.6 \mathrm{~B}$ \\
\hline 101 & RWE Group & Germany & $\$ 67.9 \mathrm{~B}$ & $\$ 4.4 \mathrm{~B}$ & $\$ 121.7 \mathrm{~B}$ & $\$ 35.4 \mathrm{~B}$ \\
\hline 103 & Unilever & Netherlands & $\$ 59.3 \mathrm{~B}$ & $\$ 5.7 \mathrm{~B}$ & $\$ 54.8 \mathrm{~B}$ & $\$ 91.9 \mathrm{~B}$ \\
\hline 104 & Comcast & United States & $\$ 37.9 \mathrm{~B}$ & $\$ 3.6 \mathrm{~B}$ & $\$ 118.5 \mathrm{~B}$ & $\$ 68.7$ B \\
\hline 105 & Kraft Foods & United States & $\$ 49.2 \mathrm{~B}$ & $\$ 4.1 \mathrm{~B}$ & $\$ 95.3 \mathrm{~B}$ & $\$ 55.4 \mathrm{~B}$ \\
\hline 106 & UnitedHealth Group & United States & $\$ 94.2 \mathrm{~B}$ & $\$ 4.6 \mathrm{~B}$ & $\$ 63.1 \mathrm{~B}$ & $\$ 47.7 \mathrm{~B}$ \\
\hline 107 & Oracle & United States & $\$ 32 \mathrm{~B}$ & $\$ 6.8 \mathrm{~B}$ & $\$ 67.2 \mathrm{~B}$ & $\$ 161.2 \mathrm{~B}$ \\
\hline 108 & Tesco & United Kingdom & $\$ 79.6$ B & $\$ 3.5 \mathrm{~B}$ & $\$ 70.1 \mathrm{~B}$ & $\$ 50.5 \mathrm{~B}$ \\
\hline 110 & Walt Disney & United States & $\$ 39 \mathrm{~B}$ & $\$ 4.4 \mathrm{~B}$ & $\$ 71 \mathrm{~B}$ & $\$ 81.5 \mathrm{~B}$ \\
\hline 112 & United Technologies & United States & $\$ 54.3 \mathrm{~B}$ & $\$ 4.4 \mathrm{~B}$ & $\$ 58.5 \mathrm{~B}$ & $\$ 74.8 \mathrm{~B}$ \\
\hline 113 & Iberdrola & Spain & $\$ 40.7 \mathrm{~B}$ & $\$ 3.8 \mathrm{~B}$ & \$121 B & $\$ 45 \mathrm{~B}$ \\
\hline 114 & American Express & United States & $\$ 30.2 \mathrm{~B}$ & $\$ 4.1 \mathrm{~B}$ & \$147 B & $\$ 53.2 \mathrm{~B}$ \\
\hline 116 & Prudential Financial & United States & \$38.4 B & $\$ 3.2 \mathrm{~B}$ & \$539.9 B & $\$ 30.7 \mathrm{~B}$ \\
\hline 117 & Prudential & United Kingdom & $\$ 75.6$ B & $\$ 2.2 \mathrm{~B}$ & $\$ 408.3 \mathrm{~B}$ & $\$ 29.4 \mathrm{~B}$ \\
\hline 118 & Boeing & United States & $\$ 64.3 \mathrm{~B}$ & $\$ 3.3 \mathrm{~B}$ & $\$ 68.6 \mathrm{~B}$ & $\$ 52.7 \mathrm{~B}$ \\
\hline 119 & CVS Caremark & United States & $\$ 96.4 \mathrm{~B}$ & $\$ 3.4 \mathrm{~B}$ & $\$ 62.2 \mathrm{~B}$ & $\$ 46.5 \mathrm{~B}$ \\
\hline 120 & Google & United States & $\$ 29.3 \mathrm{~B}$ & $\$ 8.5 \mathrm{~B}$ & $\$ 57.9 \mathrm{~B}$ & \$185.8 B \\
\hline 125 & Møller-Maersk & Denmark & $\$ 56.6 \mathrm{~B}$ & $\$ 4.7 \mathrm{~B}$ & $\$ 66.5 \mathrm{~B}$ & $\$ 40.5 \mathrm{~B}$ \\
\hline 127 & Abbott Laboratories & United States & $\$ 35.2 \mathrm{~B}$ & $\$ 4.6 \mathrm{~B}$ & $\$ 59.5 \mathrm{~B}$ & $\$ 75 \mathrm{~B}$ \\
\hline 129 & AstraZeneca & United Kingdom & $\$ 33.6 \mathrm{~B}$ & $\$ 8.1 \mathrm{~B}$ & $\$ 54.8 \mathrm{~B}$ & $\$ 65.6 \mathrm{~B}$ \\
\hline 131 & US Bancorp & United States & $\$ 20.5 B$ & $\$ 3.3 \mathrm{~B}$ & $\$ 307.8 \mathrm{~B}$ & $\$ 52.2 \mathrm{~B}$ \\
\hline 133 & Anglo American & United Kingdom & $\$ 28.4 \mathrm{~B}$ & $\$ 6.6 \mathrm{~B}$ & $\$ 66.4 \mathrm{~B}$ & $\$ 66.2 \mathrm{~B}$ \\
\hline 134 & GlaxoSmithKline & United Kingdom & $\$ 44.3 \mathrm{~B}$ & $\$ 2.5 \mathrm{~B}$ & $\$ 62.1 \mathrm{~B}$ & $\$ 99.2 \mathrm{~B}$ \\
\hline 135 & Aviva & United Kingdom & $\$ 90.7 \mathrm{~B}$ & $\$ 2.3 \mathrm{~B}$ & $\$ 567.9 \mathrm{~B}$ & $\$ 20.5 \mathrm{~B}$ \\
\hline 138 & Caterpillar & United States & $\$ 42.6 \mathrm{~B}$ & $\$ 2.7 \mathrm{~B}$ & $\$ 64$ B & $\$ 63.9 \mathrm{~B}$ \\
\hline 140 & Dow Chemical & United States & $\$ 53.7 \mathrm{~B}$ & $\$ 2.3 \mathrm{~B}$ & $\$ 69.6 \mathrm{~B}$ & $\$ 43 \mathrm{~B}$ \\
\hline
\end{tabular}




\begin{tabular}{|c|c|c|c|c|c|c|}
\hline Rank & Company & Country & Sales & Profits & Assets & Market Value \\
\hline 142 & Home Depot & United States & $\$ 68 \mathrm{~B}$ & $\$ 3.3 \mathrm{~B}$ & $\$ 40.1 \mathrm{~B}$ & $\$ 60.9 \mathrm{~B}$ \\
\hline 146 & Vivendi & France & $\$ 38.7 \mathrm{~B}$ & $\$ 2.9 \mathrm{~B}$ & $\$ 76.7 \mathrm{~B}$ & $\$ 33.8 \mathrm{~B}$ \\
\hline 147 & Bayer Group & Germany & $\$ 47 \mathrm{~B}$ & \$1.7 B & $\$ 67.5 \mathrm{~B}$ & $\$ 62.5 \mathrm{~B}$ \\
\hline 149 & News Corp & United States & $\$ 33.1 \mathrm{~B}$ & $\$ 3.1 \mathrm{~B}$ & $\$ 56.7 \mathrm{~B}$ & $\$ 45.5 \mathrm{~B}$ \\
\hline 150 & Vinci & France & $\$ 45.5 \mathrm{~B}$ & $\$ 2.4 \mathrm{~B}$ & $\$ 75.5 \mathrm{~B}$ & $\$ 32.9 \mathrm{~B}$ \\
\hline 151 & Marathon Oil & United States & $\$ 67.1 \mathrm{~B}$ & $\$ 2.6 \mathrm{~B}$ & $\$ 50 \mathrm{~B}$ & $\$ 35.6 \mathrm{~B}$ \\
\hline 152 & PNC Financial Services & United States & $\$ 17.1 \mathrm{~B}$ & $\$ 3.4 \mathrm{~B}$ & $\$ 264.3 \mathrm{~B}$ & $\$ 33.1 \mathrm{~B}$ \\
\hline 153 & Philip Morris International & United States & $\$ 27.2 \mathrm{~B}$ & $\$ 7.3 \mathrm{~B}$ & $\$ 35$ B & $\$ 114.6$ B \\
\hline 154 & United Parcel Service & United States & $\$ 49.5 \mathrm{~B}$ & $\$ 3.5 \mathrm{~B}$ & $\$ 33.6 \mathrm{~B}$ & $\$ 73.1 \mathrm{~B}$ \\
\hline 155 & Target & United States & $\$ 67.4 \mathrm{~B}$ & $\$ 2.9 \mathrm{~B}$ & $\$ 43.7 \mathrm{~B}$ & $\$ 35.7 \mathrm{~B}$ \\
\hline 158 & Occidental Petroleum & United States & $\$ 19.2 \mathrm{~B}$ & $\$ 4.5 \mathrm{~B}$ & $\$ 52.4 \mathrm{~B}$ & $\$ 80.3 \mathrm{~B}$ \\
\hline 159 & British Amer Tobacco & United Kingdom & $\$ 23.2 \mathrm{~B}$ & $\$ 4.5 \mathrm{~B}$ & $\$ 43 \mathrm{~B}$ & $\$ 76.6 \mathrm{~B}$ \\
\hline 161 & Nokia & Finland & $\$ 56.8 \mathrm{~B}$ & $\$ 2.5 \mathrm{~B}$ & $\$ 50.3 \mathrm{~B}$ & $\$ 31.2 \mathrm{~B}$ \\
\hline 162 & Renault & France & $\$ 52.2 \mathrm{~B}$ & $\$ 4.6 \mathrm{~B}$ & $\$ 93.1 \mathrm{~B}$ & $\$ 16.7 \mathrm{~B}$ \\
\hline 163 & Time Warner & United States & $\$ 26.9 \mathrm{~B}$ & $\$ 2.6 \mathrm{~B}$ & $\$ 66.5 \mathrm{~B}$ & $\$ 39.7 \mathrm{~B}$ \\
\hline 166 & Travelers Cos & United States & $\$ 25.1 \mathrm{~B}$ & $\$ 3.2 \mathrm{~B}$ & \$105.2 B & $\$ 25.4 \mathrm{~B}$ \\
\hline 167 & WellPoint & United States & $\$ 58.8 \mathrm{~B}$ & $\$ 2.9 \mathrm{~B}$ & $\$ 50.2 \mathrm{~B}$ & $\$ 25.5 \mathrm{~B}$ \\
\hline 168 & Deutsche Post & Germany & $\$ 68.3 \mathrm{~B}$ & $\$ 3.4 \mathrm{~B}$ & $\$ 50.5 \mathrm{~B}$ & $\$ 21.7 \mathrm{~B}$ \\
\hline 170 & Merck \& Co & United States & $\$ 46$ B & $\$ 861 \mathrm{M}$ & $\$ 105.8 \mathrm{~B}$ & $\$ 100.9 \mathrm{~B}$ \\
\hline 173 & EI du Pont de Nemours & United States & $\$ 32.7 \mathrm{~B}$ & $\$ 3 \mathrm{~B}$ & $\$ 40.4 \mathrm{~B}$ & $\$ 48.8 \mathrm{~B}$ \\
\hline 174 & BG Group & United Kingdom & $\$ 17.4 \mathrm{~B}$ & $\$ 3.4 \mathrm{~B}$ & $\$ 50 \mathrm{~B}$ & $\$ 79.2 \mathrm{~B}$ \\
\hline 176 & Bank of New York Mellon & United States & $\$ 14.5 \mathrm{~B}$ & $\$ 2.5 \mathrm{~B}$ & $\$ 247.3 \mathrm{~B}$ & $\$ 36 \mathrm{~B}$ \\
\hline 181 & McDonald's & United States & $\$ 24.1 \mathrm{~B}$ & $\$ 4.9 \mathrm{~B}$ & $\$ 32 \mathrm{~B}$ & $\$ 80.1 \mathrm{~B}$ \\
\hline 182 & Dell & United States & $\$ 61.5 \mathrm{~B}$ & $\$ 2.6 \mathrm{~B}$ & $\$ 38.6 \mathrm{~B}$ & $\$ 29.5 \mathrm{~B}$ \\
\hline 183 & Aegon & Netherlands & $\$ 42.4 \mathrm{~B}$ & $\$ 2.4 \mathrm{~B}$ & $\$ 445.8 \mathrm{~B}$ & $\$ 14.2 \mathrm{~B}$ \\
\hline 184 & Capital One Financial & United States & $\$ 19.1 \mathrm{~B}$ & $\$ 2.7 \mathrm{~B}$ & $\$ 197.5 \mathrm{~B}$ & $\$ 22.7 \mathrm{~B}$ \\
\hline 188 & Aflac & United States & $\$ 20.7 \mathrm{~B}$ & $\$ 2.3 \mathrm{~B}$ & $\$ 101 \mathrm{~B}$ & $\$ 26.1 \mathrm{~B}$ \\
\hline 190 & $3 \mathrm{M}$ & United States & $\$ 26.7 \mathrm{~B}$ & $\$ 4.1 \mathrm{~B}$ & $\$ 30.2 \mathrm{~B}$ & $\$ 65.2 \mathrm{~B}$ \\
\hline 192 & Lockheed Martin & United States & $\$ 45.8 \mathrm{~B}$ & $\$ 2.9 \mathrm{~B}$ & $\$ 35.1 \mathrm{~B}$ & $\$ 28.2 \mathrm{~B}$ \\
\hline 193 & L'Oréal Group & France & $\$ 26.1 \mathrm{~B}$ & $\$ 3 \mathrm{~B}$ & \$31.4 B & $\$ 67.9 \mathrm{~B}$ \\
\hline 194 & Honeywell International & United States & $\$ 33.4 \mathrm{~B}$ & $\$ 2 \mathrm{~B}$ & $\$ 37.8 \mathrm{~B}$ & $\$ 44.1 \mathrm{~B}$ \\
\hline 195 & Volvo Group & Sweden & $\$ 39.4 \mathrm{~B}$ & $\$ 1.6 \mathrm{~B}$ & $\$ 45.5 \mathrm{~B}$ & $\$ 34.8 \mathrm{~B}$ \\
\hline 196 & Schneider Electric & France & $\$ 26.2 \mathrm{~B}$ & $\$ 2.3 \mathrm{~B}$ & $\$ 40.3 \mathrm{~B}$ & $\$ 43.3 \mathrm{~B}$ \\
\hline 196 & National Grid & United Kingdom & $\$ 20.7 \mathrm{~B}$ & $\$ 2.1 \mathrm{~B}$ & $\$ 66.1 \mathrm{~B}$ & $\$ 32 \mathrm{~B}$ \\
\hline 198 & Archer Daniels & United States & $\$ 68.6 \mathrm{~B}$ & $\$ 1.9 \mathrm{~B}$ & $\$ 42.6 \mathrm{~B}$ & $\$ 23 \mathrm{~B}$ \\
\hline 199 & Lowe's Cos & United States & $\$ 48.8 \mathrm{~B}$ & $\$ 2 \mathrm{~B}$ & $\$ 33.7 \mathrm{~B}$ & $\$ 36.5 \mathrm{~B}$ \\
\hline 200 & Deere \& Co & United States & $\$ 27.3 \mathrm{~B}$ & $\$ 2.1 \mathrm{~B}$ & $\$ 42.9 \mathrm{~B}$ & $\$ 37 \mathrm{~B}$ \\
\hline 201 & Amgen & United States & $\$ 15.1 \mathrm{~B}$ & $\$ 4.6 \mathrm{~B}$ & $\$ 43.5 \mathrm{~B}$ & $\$ 49.9$ B \\
\hline 204 & Imperial Tobacco Group & United Kingdom & $\$ 23.6$ B & $\$ 2.4 \mathrm{~B}$ & $\$ 48$ B & $\$ 32.2 \mathrm{~B}$ \\
\hline 206 & Walgreen & United States & $\$ 68.4 \mathrm{~B}$ & $\$ 2.2 \mathrm{~B}$ & $\$ 27 \mathrm{~B}$ & $\$ 38.7 \mathrm{~B}$ \\
\hline 207 & Eli Lilly \& Co & United States & $\$ 23.1 \mathrm{~B}$ & $\$ 5.1 \mathrm{~B}$ & $\$ 31 \mathrm{~B}$ & $\$ 40.4 \mathrm{~B}$ \\
\hline 208 & Altria Group & United States & $\$ 16.9 \mathrm{~B}$ & $\$ 3.9 \mathrm{~B}$ & $\$ 37.4 \mathrm{~B}$ & $\$ 52.4 \mathrm{~B}$ \\
\hline 210 & Philips & Netherlands & $\$ 34 \mathrm{~B}$ & \$1.9 B & $\$ 41.5 \mathrm{~B}$ & $\$ 30.4 \mathrm{~B}$ \\
\hline 211 & Union Pacific & United States & $\$ 17 \mathrm{~B}$ & $\$ 2.8 \mathrm{~B}$ & $\$ 43.1 \mathrm{~B}$ & $\$ 46.5 \mathrm{~B}$ \\
\hline 215 & Ericsson & Sweden & $\$ 30.3 \mathrm{~B}$ & \$1.7 B & $\$ 40 \mathrm{~B}$ & $\$ 40 \mathrm{~B}$ \\
\hline
\end{tabular}




\begin{tabular}{|c|c|c|c|c|c|c|}
\hline Rank & Company & Country & Sales & Profits & Assets & Market Value \\
\hline 216 & Exelon & United States & $\$ 18.6$ B & $\$ 2.6 \mathrm{~B}$ & $\$ 52.2 \mathrm{~B}$ & $\$ 28.6 \mathrm{~B}$ \\
\hline 216 & Christian Dior & France & $\$ 28.3 \mathrm{~B}$ & \$1.7 B & $\$ 55.3 \mathrm{~B}$ & $\$ 25.7 \mathrm{~B}$ \\
\hline 218 & Danone & France & $\$ 22.8 \mathrm{~B}$ & $\$ 2.5 \mathrm{~B}$ & $\$ 35.9 \mathrm{~B}$ & $\$ 39.7 \mathrm{~B}$ \\
\hline 222 & Freeport Copper & United States & \$19 B & $\$ 4.3 \mathrm{~B}$ & \$29.4 B & $\$ 46.8 \mathrm{~B}$ \\
\hline 222 & ACE & Switzerland & $\$ 16 \mathrm{~B}$ & $\$ 3.1 \mathrm{~B}$ & $\$ 83.4 \mathrm{~B}$ & $\$ 20.6 \mathrm{~B}$ \\
\hline 224 & General Dynamics & United States & $\$ 32.5 \mathrm{~B}$ & $\$ 2.6 \mathrm{~B}$ & $\$ 32.5 \mathrm{~B}$ & $\$ 28.4 \mathrm{~B}$ \\
\hline 225 & Southern Co & United States & $\$ 17.5 \mathrm{~B}$ & $\$ 2 \mathrm{~B}$ & $\$ 55 \mathrm{~B}$ & $\$ 32.4 \mathrm{~B}$ \\
\hline 225 & Metro AG & Germany & $\$ 90.2 \mathrm{~B}$ & \$1.1 B & $\$ 47 \mathrm{~B}$ & $\$ 23 \mathrm{~B}$ \\
\hline 227 & Centrica & United Kingdom & $\$ 35 \mathrm{~B}$ & $\$ 3 \mathrm{~B}$ & $\$ 29.8 \mathrm{~B}$ & $\$ 27.4 \mathrm{~B}$ \\
\hline 229 & Hess & United States & $\$ 33.9 \mathrm{~B}$ & $\$ 2.1 \mathrm{~B}$ & $\$ 35.4 \mathrm{~B}$ & $\$ 27.1 \mathrm{~B}$ \\
\hline 231 & Bristol-Myers Squibb & United States & $\$ 19.5 \mathrm{~B}$ & $\$ 3.1 \mathrm{~B}$ & $\$ 31.1 \mathrm{~B}$ & $\$ 45 \mathrm{~B}$ \\
\hline 235 & ThyssenKrupp Group & Germany & $\$ 58.1 \mathrm{~B}$ & \$1.1 B & $\$ 58.9 \mathrm{~B}$ & $\$ 20 \mathrm{~B}$ \\
\hline 238 & TeliaSonera & Sweden & $\$ 15.9 \mathrm{~B}$ & $\$ 3.2 \mathrm{~B}$ & $\$ 35.9 \mathrm{~B}$ & $\$ 38.2 \mathrm{~B}$ \\
\hline 241 & EADS & Netherlands & $\$ 60.7 \mathrm{~B}$ & $\$ 733.6 \mathrm{M}$ & $\$ 111.2 \mathrm{~B}$ & $\$ 22 \mathrm{~B}$ \\
\hline 242 & Apache & United States & $\$ 12.1 \mathrm{~B}$ & $\$ 3 \mathrm{~B}$ & $\$ 43.4 \mathrm{~B}$ & $\$ 45.5 \mathrm{~B}$ \\
\hline 245 & Carrefour Group & France & $\$ 120.6$ B & $\$ 579.7 \mathrm{M}$ & \$70.9 B & $\$ 31.2 \mathrm{~B}$ \\
\hline 246 & Costco Wholesale & United States & $\$ 82 \mathrm{~B}$ & $\$ 1.4 \mathrm{~B}$ & $\$ 25.7 \mathrm{~B}$ & $\$ 31.7 \mathrm{~B}$ \\
\hline 247 & Medtronic & United States & $\$ 15.8 \mathrm{~B}$ & $\$ 3.3 \mathrm{~B}$ & $\$ 30.6 \mathrm{~B}$ & $\$ 40.7 \mathrm{~B}$ \\
\hline 248 & SAP & Germany & \$16.7 B & $\$ 2.4 \mathrm{~B}$ & $\$ 27.8 \mathrm{~B}$ & $\$ 71.9 \mathrm{~B}$ \\
\hline 250 & BT Group & United Kingdom & $\$ 31.7 \mathrm{~B}$ & \$1.6 B & $\$ 40.2 \mathrm{~B}$ & $\$ 23.4 \mathrm{~B}$ \\
\hline 252 & Qualcomm & United States & \$11.7 B & $\$ 3.6 \mathrm{~B}$ & $\$ 31.3 \mathrm{~B}$ & $\$ 88.1 \mathrm{~B}$ \\
\hline 254 & Dominion Resources & United States & $\$ 15.2 \mathrm{~B}$ & $\$ 2.8 \mathrm{~B}$ & $\$ 42.8 \mathrm{~B}$ & \$26.4 B \\
\hline 255 & EMC & United States & $\$ 17 \mathrm{~B}$ & \$1.9 B & $\$ 30.8 \mathrm{~B}$ & $\$ 55 \mathrm{~B}$ \\
\hline 258 & Hartford Finl Svcs & United States & $\$ 22.4 \mathrm{~B}$ & \$1.7 B & \$318.3 B & $\$ 12.3 \mathrm{~B}$ \\
\hline 260 & Bouygues & France & $\$ 41.8 \mathrm{~B}$ & $\$ 1.4 \mathrm{~B}$ & $\$ 47.4 \mathrm{~B}$ & $\$ 16.5 \mathrm{~B}$ \\
\hline 264 & Allstate & United States & $\$ 31.4 \mathrm{~B}$ & $\$ 928 \mathrm{M}$ & $\$ 130.9 \mathrm{~B}$ & \$16.9 B \\
\hline 267 & NextEra Energy & United States & $\$ 15.3 \mathrm{~B}$ & $\$ 2 \mathrm{~B}$ & $\$ 53 \mathrm{~B}$ & $\$ 23.4 \mathrm{~B}$ \\
\hline 269 & Gas Natural Group & Spain & $\$ 26.3 \mathrm{~B}$ & $\$ 1.6 \mathrm{~B}$ & $\$ 59.5 \mathrm{~B}$ & $\$ 15.4 \mathrm{~B}$ \\
\hline 271 & Holcim & Switzerland & $\$ 23.2 \mathrm{~B}$ & $\$ 1.3 \mathrm{~B}$ & $\$ 47.1 \mathrm{~B}$ & $\$ 23.4 \mathrm{~B}$ \\
\hline 272 & Northrop Grumman & United States & $\$ 34.8 \mathrm{~B}$ & $\$ 2.1 \mathrm{~B}$ & \$31.4 B & \$19.3 B \\
\hline 275 & Air Liquide & France & $\$ 18.1 \mathrm{~B}$ & \$1.9 B & $\$ 30.2 \mathrm{~B}$ & $\$ 36.1 \mathrm{~B}$ \\
\hline 276 & Diageo & United Kingdom & $\$ 14.6$ B & $\$ 2.4 \mathrm{~B}$ & $\$ 28.3 \mathrm{~B}$ & $\$ 47.3 \mathrm{~B}$ \\
\hline 278 & Emerson Electric & United States & $\$ 21.7 \mathrm{~B}$ & $\$ 2.2 \mathrm{~B}$ & $\$ 22.7 \mathrm{~B}$ & $\$ 44.8 \mathrm{~B}$ \\
\hline 279 & McKesson & United States & \$109.9 B & $\$ 1.1 \mathrm{~B}$ & $\$ 30.4 \mathrm{~B}$ & $\$ 19.8 \mathrm{~B}$ \\
\hline 281 & Johnson Controls & United States & $\$ 35.4 \mathrm{~B}$ & $\$ 1.5 \mathrm{~B}$ & $\$ 26 \mathrm{~B}$ & $\$ 27.6 \mathrm{~B}$ \\
\hline 282 & FedEx & United States & $\$ 38.2 \mathrm{~B}$ & $\$ 1.3 \mathrm{~B}$ & $\$ 26.2 \mathrm{~B}$ & $\$ 28.6 \mathrm{~B}$ \\
\hline 282 & BlackRock & United States & $\$ 8.6 \mathrm{~B}$ & $\$ 2.1 \mathrm{~B}$ & $\$ 178.5 \mathrm{~B}$ & $\$ 25 \mathrm{~B}$ \\
\hline 284 & BAE Systems & United Kingdom & $\$ 32.9 \mathrm{~B}$ & \$1.6 B & $\$ 35.8 \mathrm{~B}$ & $\$ 17.5 \mathrm{~B}$ \\
\hline 286 & Time Warner Cable & United States & $\$ 18.9 \mathrm{~B}$ & $\$ 1.3 \mathrm{~B}$ & $\$ 45.8 \mathrm{~B}$ & $\$ 23.6 \mathrm{~B}$ \\
\hline 290 & Duke Energy & United States & $\$ 14.3 \mathrm{~B}$ & \$1.3 B & $\$ 59.1 \mathrm{~B}$ & $\$ 24.5 \mathrm{~B}$ \\
\hline 291 & Telenor & Norway & $\$ 16.3 \mathrm{~B}$ & $\$ 2.5 \mathrm{~B}$ & $\$ 29.4 \mathrm{~B}$ & $\$ 26.7 \mathrm{~B}$ \\
\hline 292 & \begin{tabular}{|l|} 
Devon Energy \\
\end{tabular} & United States & $\$ 9.9 \mathrm{~B}$ & $\$ 4.6 \mathrm{~B}$ & $\$ 32.9 \mathrm{~B}$ & $\$ 37.6 \mathrm{~B}$ \\
\hline 298 & State Street & United States & $\$ 9.7 \mathrm{~B}$ & $\$ 1.6 \mathrm{~B}$ & $\$ 160.5 \mathrm{~B}$ & $\$ 21.8 \mathrm{~B}$ \\
\hline 302 & Amazon.com & United States & $\$ 34.2 \mathrm{~B}$ & $\$ 1.2 \mathrm{~B}$ & $\$ 18.8 \mathrm{~B}$ & $\$ 75.8 \mathrm{~B}$ \\
\hline 303 & Aetna & United States & $\$ 34.2 \mathrm{~B}$ & \$1.8 B & $\$ 37.7 \mathrm{~B}$ & \$14 B \\
\hline
\end{tabular}




\begin{tabular}{|c|c|c|c|c|c|c|}
\hline Rank & Company & Country & Sales & Profits & Assets & Market Value \\
\hline 304 & Scottish \& Southern & United Kingdom & $\$ 32.7 \mathrm{~B}$ & $\$ 1.9 \mathrm{~B}$ & $\$ 27.3 \mathrm{~B}$ & $\$ 17.9 \mathrm{~B}$ \\
\hline 305 & Linde & Germany & \$17.3 B & $\$ 1.3 \mathrm{~B}$ & $\$ 36.1 \mathrm{~B}$ & $\$ 25.8 \mathrm{~B}$ \\
\hline 307 & Peugeot & France & $\$ 75 \mathrm{~B}$ & $\$ 1.5 \mathrm{~B}$ & $\$ 91.2 \mathrm{~B}$ & $\$ 8.7 \mathrm{~B}$ \\
\hline 307 & Veolia Environnement & France & $\$ 46.6 \mathrm{~B}$ & $\$ 777.9 \mathrm{M}$ & $\$ 66.7 \mathrm{~B}$ & $\$ 15 \mathrm{~B}$ \\
\hline 309 & EnBW-Energie Baden & Germany & $\$ 23.4 \mathrm{~B}$ & $\$ 1.6 \mathrm{~B}$ & $\$ 47.2 \mathrm{~B}$ & $\$ 14.4 \mathrm{~B}$ \\
\hline 312 & Chubb & United States & $\$ 13.3 \mathrm{~B}$ & $\$ 2.2 \mathrm{~B}$ & $\$ 50.2 \mathrm{~B}$ & $\$ 17.4 \mathrm{~B}$ \\
\hline 313 & Loews & United States & \$14.6 B & $\$ 1.3 \mathrm{~B}$ & $\$ 76.3 \mathrm{~B}$ & $\$ 17.4 \mathrm{~B}$ \\
\hline 314 & Lafarge & France & $\$ 21.6 \mathrm{~B}$ & $\$ 1.1 \mathrm{~B}$ & $\$ 56.4 \mathrm{~B}$ & $\$ 16.7 \mathrm{~B}$ \\
\hline 319 & Danske Bank Group & Denmark & $\$ 21.7 \mathrm{~B}$ & $\$ 657 \mathrm{M}$ & $\$ 578.3 \mathrm{~B}$ & $\$ 15.6 \mathrm{~B}$ \\
\hline 320 & Alstom & France & $\$ 26.6 \mathrm{~B}$ & $\$ 1.6 \mathrm{~B}$ & $\$ 33.8 \mathrm{~B}$ & $\$ 15.9 \mathrm{~B}$ \\
\hline 326 & EDP-Energias de Portugal & Portugal & $\$ 19$ B & $\$ 1.4 \mathrm{~B}$ & $\$ 53.7 \mathrm{~B}$ & $\$ 13.9 \mathrm{~B}$ \\
\hline 336 & PPR & France & $\$ 19.6 \mathrm{~B}$ & $\$ 1.3 \mathrm{~B}$ & $\$ 32.4 \mathrm{~B}$ & $\$ 19 \mathrm{~B}$ \\
\hline 341 & Reckitt Benckiser Group & United Kingdom & $\$ 13.2 \mathrm{~B}$ & $\$ 2.4 \mathrm{~B}$ & $\$ 20.7 \mathrm{~B}$ & $\$ 36.2 \mathrm{~B}$ \\
\hline 343 & Koç Holding & Turkey & $\$ 35.9 \mathrm{~B}$ & $\$ 1.2 \mathrm{~B}$ & $\$ 52.5 \mathrm{~B}$ & $\$ 10.8 \mathrm{~B}$ \\
\hline 346 & Henkel Group & Germany & $\$ 20.2 \mathrm{~B}$ & $\$ 1.5 \mathrm{~B}$ & $\$ 23 \mathrm{~B}$ & $\$ 24.4 \mathrm{~B}$ \\
\hline 352 & CEZ & Czech Republic & $\$ 10.6 \mathrm{~B}$ & $\$ 2.5 \mathrm{~B}$ & $\$ 29 \mathrm{~B}$ & $\$ 24.6 \mathrm{~B}$ \\
\hline 358 & Fiat Group & Italy & $\$ 48 \mathrm{~B}$ & $\$ 696.1 \mathrm{M}$ & $\$ 96.3 \mathrm{~B}$ & $\$ 10.9 \mathrm{~B}$ \\
\hline 363 & OMV Group & Austria & $\$ 31.2 \mathrm{~B}$ & $\$ 1.2 \mathrm{~B}$ & $\$ 35.2 \mathrm{~B}$ & $\$ 12.5 \mathrm{~B}$ \\
\hline 376 & Ferrovial & Spain & $\$ 16.1 \mathrm{~B}$ & $\$ 2.9 \mathrm{~B}$ & $\$ 55.3 \mathrm{~B}$ & $\$ 9.2 \mathrm{~B}$ \\
\hline 378 & Continental & Germany & $\$ 34.9 \mathrm{~B}$ & $\$ 771.1 \mathrm{M}$ & $\$ 31.8 \mathrm{~B}$ & $\$ 16.8 \mathrm{~B}$ \\
\hline 381 & Areva & France & $\$ 12.2 \mathrm{~B}$ & $\$ 1.2 \mathrm{~B}$ & $\$ 46.3 \mathrm{~B}$ & $\$ 17.1 \mathrm{~B}$ \\
\hline
\end{tabular}


Table 2: The number of companies by country of residence.

\begin{tabular}{|c|c|}
\hline Row Labels & Count of Company \\
\hline Austria & 1 \\
\hline Belgium & 1 \\
\hline Czech Republic & 1 \\
\hline Denmark & 2 \\
\hline Finland & 1 \\
\hline France & 24 \\
\hline Germany & 19 \\
\hline Italy & 3 \\
\hline Luxembourg & 1 \\
\hline Netherlands & 6 \\
\hline Norway & 2 \\
\hline Portugal & 1 \\
\hline Spain & 7 \\
\hline Sweden & 3 \\
\hline Switzerland & 7 \\
\hline Turkey & 1 \\
\hline United Kingdom & 20 \\
\hline United States & 100 \\
\hline Total & 200 \\
\hline
\end{tabular}


Table 3: Effective tax rates for each region by year. Revenue Ratio is the ratio of total U.S. revenues to total European revenues. It can be regarded as a measure of business volume.

\begin{tabular}{|r|r|r|l|}
\hline \multicolumn{1}{|l|}{ Year } & Europe & \multicolumn{1}{l|}{ US } & $\begin{array}{l}\text { Revenue Ratio } \\
\text { (US/EU) }\end{array}$ \\
\hline 2001 & $39 \%$ & $33 \%$ & 1.19 \\
\hline 2002 & $49 \%$ & $32 \%$ & 1.06 \\
\hline 2003 & $34 \%$ & $24 \%$ & 0.99 \\
\hline 2004 & $31 \%$ & $27 \%$ & 1.02 \\
\hline 2005 & $34 \%$ & $30 \%$ & 1.20 \\
\hline 2006 & $32 \%$ & $31 \%$ & 1.16 \\
\hline 2007 & $31 \%$ & $32 \%$ & 1.25 \\
\hline 2008 & $46 \%$ & $56 \%$ & 1.22 \\
\hline 2009 & $37 \%$ & $30 \%$ & 1.21 \\
\hline 2010 & $31 \%$ & $24 \%$ & 1.25 \\
\hline \hline $2001-2010$ & $35 \%$ & $31 \%$ & 1.16 \\
\hline Excluding 2008 & $34 \%$ & $29 \%$ & 1.15 \\
\hline $2001-2007$ & $34 \%$ & $30 \%$ & 1.13 \\
\hline
\end{tabular}


Avi-Yonah and Lahav:

Table 4: Effective tax rates of each region, by industry, for 2001 - 2010. Numbers in bold represent lower AETR.

\begin{tabular}{|l|r|r|}
\hline Industry & Europe & US \\
\hline Mining & $\mathbf{2 8 \%}$ & $40 \%$ \\
\hline Manufacturing & $39 \%$ & $\mathbf{2 8 \%}$ \\
\hline Transportation & $32 \%$ & $\mathbf{2 3 \%}$ \\
\hline Trade & $\mathbf{2 8 \%}$ & $34 \%$ \\
\hline Finance & $\mathbf{2 5 \%}$ & $37 \%$ \\
\hline Service & $35 \%$ & $\mathbf{2 5 \%}$ \\
\hline Public Administration & $29 \%$ & $\mathbf{2 0 \%}$ \\
\hline \hline Total & $35 \%$ & $\mathbf{3 1 \%}$ \\
\hline
\end{tabular}


Figure 1: Distibution of companies by industry segment for US and Europe seperately.

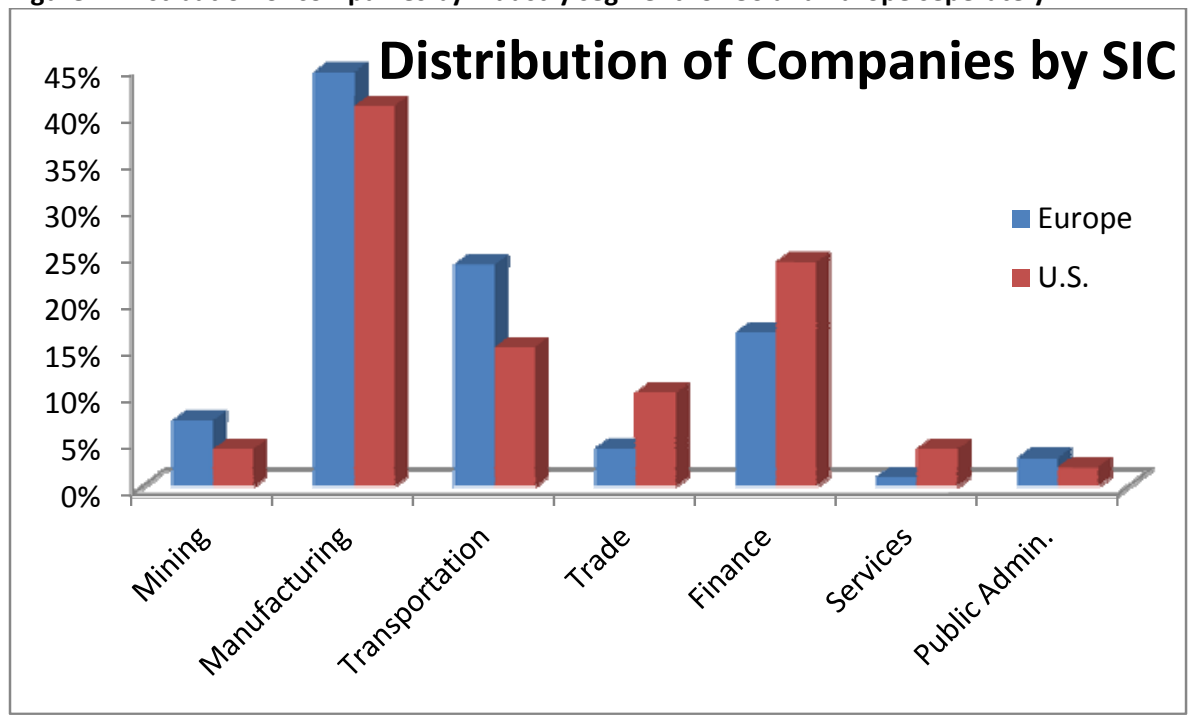

